\title{
Český heldentenor Joseph Aloys Tichatscheck \\ a jeho první spolupráce s Richardem Wagnerem
}

\section{Czech Heldentenor Joseph Aloys Tichatscheck and his first cooperation with Richard Wagner}

\author{
Martin Kajzar / martin.kajzar@osu.cz \\ Department of Musical Education, Faculty of Education, University of Ostrava, Ostrava, CZ
}

\begin{abstract}
Joseph Aloys Tichatscheck was one of the distinctive figures of singing not just for his original performances of the operas and music dramas by Richard Wagner, but also for his artistic complexity. He was practically a symbol of singing of Wagner's music drama and a true archetype of the Heldentenor. During Wagner's life, moreover, he became a major promoter of the composer's work. Article was founded on research of sources both in the Czech Republic as well as abroad (Bayreuth, Berlin, Dresden, Frankfurt, Leipzig, Moscow, Neuruppin, Vienna), but also thanks to digitized global archives and national libraries, documents, handwritten materials, newspaper and magazine reviews, photographs and family memories. Today it is more than two centuries since the artist's birth, and this part of Dissertation present a complex artistic and personal profile of Joseph Tichatscheck between years 1842-1843 as the outcome of the author's original research activities.
\end{abstract}

\section{Keywords}

Tichatscheck, tenor, theater, opera, Dresden, Rienzi, Richard Wagner, Heldentenor 


\title{
Tichatscheck a Richard Wagner poprvé
}

\begin{abstract}
Jako na pruniho wagnerouského pěvce a interpreta, který pro Richarda Wagnera ztělesňoval pěvecký vzor, lze na něho také nahližet jako na spolutviorce oné slávy, která náleži tomuto básniku tónů. Tichatscheckưv Rienzi a Tannhäuser se stali přdobrazy pro německé zpěvuáky.
\end{abstract}

Eduard Langer

Rienzi, der Letzte der Tribunen (dále jen Rienzi, poslední z tribunů nebo zjednodušeně Rienzi) je velká pětiaktová opera Richarda Wagnera o šestnácti číslech. Její libreto napsal Wagner sám, stejně jako tomu bylo u všech jeho dalších děl. Inspirací mu byl román Edwarda Bulwer-Lyttona pojednávající o Colovi di Rienzo (1313-1354), výrazné osobnosti a státníkovi pozdně středověkého Ríma. Jde o příběh posledního z tribunů, který se snažil o římský převrat s cílem sjednotit Itálii. Byl odsouzen na smrt, před níž nakonec se značnou dávkou štěstí unikl. Výjimku tvoří, že se jedná (u Wagnera nezvykle) o skutečnou historickou osobnost, která byla mj. vězněna Karlem IV. Opera je ukázkou skladatelova raného období s prvky svébytné kompoziční techniky. Vychází z francouzské grand opery, jež razí cestu honosné a bohaté výpravy a striktně se drží počtu čtyř nebo pěti dějství. ${ }^{1}$ „Originál partitury Rienziho je dnes ztracen, naposled jej v letech 1939-1945 vlastnil Adolf Hitler. Ztráta originálu Rienziho je obzvlášt́ nepř́ijemná, protože sám Wagner v ní hojně škrtal, upravoval ji a předělával, takže zjistit definitivní verzi je dnes vlastně nemožné. Úpravy nelze vypočítat. Jisto je, že roku 1868 partituru Rienziho Wagner věnoval k Vánocům Ludvíku II. a že z wittelsbašského archivu se v dubnu 1939 dostala do rukou Adolfa Hitlera. “2 Toto dílo lze suverénně označit za jeden z vrcholů Tichatscheckovy kariéry, nebot, jak se shodují skladatelé i kritika, pěvec v roli doslova exceloval.

\section{Rienzi, poslední z tribunů (1842)}

Tichatscheck ještě dnes tuto roli zpívá s neochvějnou mladistvou silou a na dobrém výkonu pěvcově závisi byti této opery.

Moritz Fürstenau

Hlavní díl své slávy si Joseph Aloys Tichatscheck vydobyl coby wagnerovský pěvec a interpret německé opery a později hudebního dramatu. Jeho řešení těchto, na tehdejší hudební a operní poměry zcela neobvyklých a nanejvýš obtížných úloh zvěčnilo jeho jméno v uměleckých a hudebních dějinách Německa. Jak uvádí Illustrirte Zeitung Leipzig roku 1843, i díky jeho umělecké zásluze se vrcholný představitel německé pozdně romantické

1 BAITZEL, Edgar. Richard Wagner. Rienzi, der letzte der Tribunen: Bayrische Staatsoper München. München: Herstellung und Druck J. Gotteswinter, 1983, s. 5-20.

2 KUČERA, Jan. P. Drama zrozené hudbou. Litomyšl: Paseka, 1995, s. 58. 
opery - Richard Wagner - stal uznávaným a respektovaným skladatelem. „Při velikosti a obtižnosti díla, při mnohých silách, které bylo třeba např́t, a pečlivosti, která se tomuto plným právem věnovala, se přesto až onoho výše uvedeného dne při představeni zadařilo a dílo se objevilo jako Minerva v plné zbroji náhle uprostřed ohromeného a radostně překvapeného zástupu. $S$ každou z mnoha repriz se stupňoval potlesk."3

Wagnerovo jméno zůstává i díky Rienzimu neoddělitelně spjato s dějinami rozvoje moderní německé opery, jejímž pěvcem a ryzím archetypem Heldentenora se pozvolna v té době stával Joseph Aloys Tichatscheck. Obrovskou devízou, kterou Wagner nesčetněkrát u pěvce vyzdvihoval, byla jeho muzikalita, se kterou k jakékoliv opeře přistupoval. Ve své autobiografii Wagner s obdivem oceňuje jeho talent, pohotovost a hudební pamět. „Nemusel se na zkoušky dř́t předem svizelně zpaměti, protože byl tak muzikální, že i ty nejtěžši úseky zazpíval z listu a studium role tím pro něj bylo vyř́zeno. [...] Když měl Tichatscheck během zkoušek možnost si daný úsek několikrát zopakovat, vštípil si jej tím do paměti a pak už se jen staral o to, jak uplatnit pěvecké uměni a dramatický prednes."4

\section{K nastudování opery Rienzi}

Kde Tichatscheck co Rienzi vystoupil, tam koluje jen jedno smýšleni, jeden úsudek. Rienzi nenalezl posud' lepšiho zastupitele.

Emanuel Meliš

Richard Wagner si v té době v Paříži jen s nejvyššími obtížemi zajištoval živobytí. Zaslal tedy vcelku bez velkých nadějí partituru své prvotiny Rienzi do Drážd’an. Ve vedení opery stál tenkrát Wilhelm Fischer - režisér i sbormistr s důkladnou klasickou hudební průpravou a citem pro divadlo. Tomu se podařilo von Lüttichaua a kapelníka Reißigera pro operu zaujmout. Věci napomohl též fakt, že Reißiger udržoval dobrý vztah s Tichatscheckem, jemuž dokonce věnoval album písní, které složil. „Partitura byla nejprve prohlášena za nevyhovujicí, presto se ale podařilo diky úsili reditele sboru Wilhelma Fischera, praktickým pohledem obdařeného herce a zpěváka nejen přistupného všemu krásnému, ale nakloněného i rüzným opernim experimentiom, pro ni zaujmout Tichatschecka i Schröder-Devrientovou. "5 A tak v roce 1841 obdržel Tichatscheck v kanceláři Králouského dvorního divadla mohutnou zásilku. Byla to partitura nově vzniknuvší opery Rienzi z pera tehdy neznámého skladatele Richarda Wagnera. Balík byl natolik objemný, že většina vedení divadel již po prvním nahlédnutí do partitury zaujala stanovisko „k provozováni nevhodné".

3 BROCKHAUS, F. U. Rienzi, der Letzte der Tribunen: Große tragische Oper in fünf Acten von Richard Wagner. Illustrirte Zeitung: Leipzig, Berlin, Wien, Budapest, New York: Wöchentliche Nachrichten über alle Tagesgeschichte, öffentliches und gesellschaftliches Leben, Wissenschaft und Kunst, Musik, Theater und Moden. Leipzig: Verlag der Expedition der Illustrirten Zeitung J. J. Weber, 1843, 1 (7), s. 107-109.

4 WAGNER, Richard. Mưj život. Praha: Národní divadlo v Praze, 2007, s. 192.

5 DEMBSKI, Max. Feuilleton. Münchener allgemeine Zeitung. Dresden: Verlag der Expedition der Illustrirten Zeitung J. J. Weber, 1907, 22 (316), s. 56. 
Vzhledem k tomu, že v roce 1842 mladého Wagnera znal málokdo, lze hovořit o štěstí, že nalezl zastání v uměleckém kruhu tehdejšího drážd’anského divadla. Termín uvedení opery se neustále odsouval, ale také díky Tichatscheckovým přímluvám se Rienzi v Drážd’anech nakonec provedl. Wagner se dokonce přímo dovolával podrobnou zprávou milosti krále. ${ }^{6} \mathrm{~V}$ té písemnou formou přiblí̌̌il vưdčí osobnosti, jako např. kapelníka Reißigera, i přední umělce drážd’anského dvorního jeviště, kteří vyjádřili Wagnerovi svou podporu "právě tak lichotivě jako počestně ${ }^{\text {“. }}{ }^{7}$

I když Rienzi dnes nepatří mezi nejhranější Wagnerova díla a dosud nenese prvky přerodu opery v gesamtkunstwerk, v době svého uvedení měl jednoznačně pozitivní vliv na pozici i profilaci doposud opomíjeného skladatele, a Richard Wagner si díky němu otevřel cestu na německá jeviště. Vždyt’ Wagnerovy prvotiny, nedokončená Die Hochzeit (Svatba), Das Liebesverbot (Zakázaná láska) a Die Feen (Vily), nezaznamenaly sebemenší úspěch. Oproti tomu premiérové uvedení Rienziho v Drážd’anech mělo dopad zcela opačný a Wagner si díky této opeře podmanil domácí publikum. Zásadně se na úspěchu pětiaktového díla v duchu velké francouzské opery podepsala honosná výprava (na jevišti se objevil dokonce živý kůň) a výkony sólistů - sopranistky Wilhelmine Schröder-Devrientové a hrdinného tenora Josepha Aloyse Tichatschecka. Wagner měl v počátcích obzvláštní starost o to, zda bude Tichatscheck s to se s titulní rolí tohoto významu sblížit a sžít, avšak záhy byly jeho obavy vyvráceny.

„Žádné divadlo na světě, vyjma drážd'anské dvorni opery,“ píše Wagner, „mi nedopomůže k umělcưm silné dramatické zralosti Tichatschecka nebo Schröder-Devrientové. Jak by ale bylo možno dostát s oddanosti úkolu, jehož směrováni si člověk neni vědom: umělec musi být volný, má-li studiu role věnovat lásku a srdce! Rienzi, jenž utiká ze svého nejživějšího nitra, by měl v tom nejplnějšim smyslu slova být hrdinou - hluboce naď̌eným snilkem, který coby třpytivý paprsek světla zjevi se mezi poklesnuvším a zakrnělým lidem, by ho osvitil a pozdvihl svým voláním. "8 Postava Rienziho měla být v době příběhu, v níž se odehrává, v mladém věku osmadvaceti let; tato okolnost spolu s Wagnerovým vyhraněným názorem na pestrou povahu tenorového zpěvního hlasu přiměla skladatele k tomu, aby part napsal právě pro tenor. Tím vystoupil z okruhu tehdy obvyklého náhledu na věc, tedy že tenorový hlas odpovídá v konečném důsledku charakteru milovníka.

Když byla opera konečně 29. června 1841 přijata ředitelstvím k provedení, byl to Tichatscheck, jenž kvůli přípravám a vedení zkoušek Rienziho v létě roku 1842 do Drážd’an přišedšího Richarda Wagnera v divadle přátelsky přivítal; od tohoto dne spojovalo oba muže pouto, které vytrvalo až do Wagnerovy smrti. Wagner požádal Tichatschecka, aby s ním pilně studoval, a prohlásil, že „Rienzi bude jeho nejbrilantnějším partem, nebot’ v žádném jiném nenalezne tolik př́ležitosti se předvést “. ${ }^{9}$ Jak nás o této události zpravuje i Wagne-

6 PRÖLB, Robert. Geschichte des Hoftheaters zu Dresden: Von seinen Anfängen bis zum Jahre 1862. Dresden: Wilhelm Baensch Verlagshandlung, 1878, s. 532-533.

7 Tamtéž, s. 534.

8 ISOLANI, Eugen. Der este Wagnersänger: zum hundertjährigen Geburstage Tichatscheks. Neuer Theater Almanach: der Deutschen Bühnengenosseschaft vom Jahre 1907. Berlin: Druck und komissions Verlag von F. U. Günther \& Sohn., 1907, 18, s. 68.

9 Tamtéž. 
rův životopisec Carl Friedrich Glasenapp,,$^{10}$ popisuje Tichatschecka coby „zázračný hlas své doby“. Wagner se přesvědčil během zkoušek Rienziho brzy o tom, ,jakého věru uměleckého př́tele on a jeho dilov Tichatscheckovi ziskali. Naruistajici nadšeni a zájem hlavního zpěváka o jeho úkol, o celé dilo, prodchnul všechny ostatni pěvce povolané ke spolupráci zpưsobem tak radostným a oproti skromným divadelnim zvyklostem překvapujicim, že ho samo publikum skrze div tohoto vřelého nadšeni všech umělcư pro operu zcela neznámého autora beze jména a slávy s radosti prijalo." 11

A tak se Wagner mohl opřít o kvalitní pěvecké výkony sólistů drážd’anské opery. Schröder-Devrientová v té době již stála na vrcholu své kariéry a Tichatscheck se rovněž řadil k předním tenorům své doby. V roce 1842 měl totiž Wagner $\mathrm{k}$ dispozici mimo představitele hlavních rolí pouze průměrné síly, a tak není divu, jak často se o umělcích v ústředních úlohách zmiňuje v dochovaných textech a korespondenci. Ostatní větší role v opeře získali sopranistka Henriette Wüstová jako Irene, v roli Colonny se objevil německý basista Carl Wilhelm Dettmer, basbarytonista Johann Michael Wächter vystoupil jako Orsini a Anna Thieleová zase jako Posel míru. ${ }^{12}$ Většina osazenstva divadla rychle vycítila originalitu a novost Rienziho a pochopila, že jde o něco víc než obyčejnou divadelní novinku, jakým se často nevyplatilo věnovat námahu. I Tichatscheck si uvědomoval, že jde o zcela jiné hudební dílo, než dosud poznal. V dopise malíři Ernstu Benediktu Kietzemu ze dne 6. září roku 1842 se Wagner směrem k Tichatscheckovi a k jeho studiu operního partu vyjadřoval jako o interpretačním ideálu. „Tichatscheck - jeho hlas je , dělaný na míru' - dèlaný pro mého Rienziho. Tichatscheck považoval roli za to nejlepší, co kdy zpíval. Budu mít bohatě zdobené brněni vyrobené z nefalšovaného střibra, které bude stát 400 tolarü."13 Díky prostoru, který v Drážd’anech nakonec Wagnerův Rienzi dostal, lze hovořit o vzájemné symbióze fenoménů většího významu a přetavení vložené práce a úsilí v úspěch. Na provedení Rienziho narostla jak hodnota orchestru a umělecká hloubka drážd’anského souboru vedeného Reißigerem a Rastrellim, tak jméno Wagnerovo.

10 Carl Friedrich Glasenapp (1847-1915) byl ruský státní rada a wagnerovský badatel. Na univerzitě v Tartu vystudoval klasickou filologii, historii umění a srovnávací jazykovědy. Působil též jako učitel německého jazyka a literatury na škole v Rize. Pro jeho filologické studium písemností a hudby Richarda Wagnera byl častým návštěvníkem Bayreuther Festspiele a rodinným hostem ve vile Wahnfried. Zde v něm postupně dozrávalo rozhodnutí popsat detailně život a dílo skladatele. Tak vydal v roce 1877, jako vůbec první, Wagnerův životopis (ve dvou svazcích). Spolu s publicistou Heinrichem Freiherrem von Steinem vydal roku 1883 Wagnerův Lexikon a v roce 1891 publikoval svou dvoudílnou Encyklopedii Wagner. Vzhledem k rozsáhlé Wagnerově korespondenci byla provedena nutná revize životopisu, který pak byl publikován v roce 1911 pod názvem Život Richarda Wagnera v šesti svazcích (3107 stran), což je považováno za jeho životní dílo. Roku 1903 byl dokonce nominován na Nobelovu cenu za literaturu. Po Glasenappově smrti v roce 1915 byl jeho majetek použit k založení památníku Richarda Wagnera v Bayreuthu. Rovněž je po něm pojmenována přilehlá ulice Glasenappweg. Památník s knihovnou nyní čítá okolo 11000 svazků, které jsou postupně integrovány do Muzea Richarda Wagnera. Zdroj: STERNFELD, Richard. Zu C. Fr. Glasenapps sechzigstem Geburstag: Leitartikel, Biographien etc. Musikalisches Wochenblatt: Organ für Musiker und Musikfreunde. Neue Zeitschrift für Musik. Berlin. Leipzig. Wien: Kommissions-Verlag von G. Kreysing, 1907, 38 (40), s. 794-795.

11 ESCHEBACH, Erika a Erik OMLOR. Richard Wagner in Dresden. Mythos und Geschichte. Dresden: Stadtmuseum Dresden, 2013, s. 142.

12 Tamtéž.

13 BATTA, András. OPERA. Composers. Works. Performers. England, 2009, s. 757. 


\section{K premiéře opery Rienzi}

Stoje na vrcholu umèlecké činnosti a maje v rukou moc hlasu, plný sily a zralého mužství dosáhl umèlec na piedestal své slávy skrze oheñ dramatické vášně a impozantního výrazu. Postavě řimského hrdiny svobody a tribuna lidu dokázal skrze věru strhujici výř̌čnost propijočit neopakovatelné kouzlo. Dosáhl nezměrného úspěchu, jenž pomohl nejen jeho osobě, ale také dílu samotnému, a jeho spřátelenému skladateli.

Eduard Langer

Dne 20. ř́ijna 1842 se v drážd’anském Královském dvorním divadle konala světová premiéra pětiaktové opery Richarda Wagnera - Rienzi, posledni z tribunů, kde se Tichatscheck publiku představil v ústřední roli Coly Rienziho a Schröder-Devrientová v kalhotkové roli Adriana. Leipziger Zeitung o premiérovém představení informovaly jako o jednoznačném úspěchu. „Rok 1842 byl pro Tichatscheckưv bohatý umělecký život doslova přelomový. Skladatel na premiéru představeni príjel z Pařiže a dostalo se mu navzdory bezmála šestihodinové délce inscenace zcela jednoznačného potlesku. "14 Sám zdůraznil: „Pro Drážd’any jsem se rozhodl, protože jsem věděl, že je tam tenorista Tichatscheck, který byl pro hlavni roli ideálni. "15 Z dopisů datovaných z období premiéry je doložitelné, o jak významnou událost ve Wagnerově životě šlo. S neutuchajícím nadšením psal Richard Wagner o provedení Rienziho v Drážd’anech své sestře Cecílii a jejímu muži Eduardu Avenariusovi dopis datovaný 21. října 1842 do Pař́iže. „Byla to doslova pandemie, revoluce v celém městě; byl jsem čtyřikrát za neutuchajicího potlesku vyzván na scénu. Lidé mne ujistili, že úspěch Meyerbeerových Hugenotů byl ničím ve srovnáni s Rienzim. I třetí večer byla všechna mista vyprodána. Představeni bylo mimorádně vydařené - Tichatscheck - Devrientová - vše - vše bylo perfektní, něco dosud nevídaného. Úspěch! Úspěch!... ten den nastal [...]“16

Pochvaly o nezdolné výdrži Tichatscheckova zpěvního hlasu a také o jeho fyzické síle a odolnosti ve více než šest hodin trvajícím prvním provedení popisuje také již zmíněný Wagnerův životopisec Carl Friedrich Glasenapp. „Především Tichatscheck se zhostil svého úkolu duchem a silou, s neochvějnou jistotou hlasu v jeho zářivém, hrdinném, strhujicím ztvárnění v mimice vyjádřil mnohé svýma mladýma velikýma očima, a jeho krásný hlas byl do poslední noty zřetelný, přestože part tribunưv byl tehdy o mnoho silněji instrumentován nežli nyni, kdy Wagner provedl několik pročištěni partitury. "17 Partitura měla na tehdejší poměry mohutnou instrumentaci, a opera také trvala o mnoho déle, než bylo dosud obvyklé. Skladatel sám učinil v textu výrazné škrty a zkrácení. Glasenapp dále píše: „Setkávaji se zde majestát a mírnost, které jejich mocný hlasatel nechává rozeznít v celé lidské duši. Nanejuýš důležitá je správná deklamace textu, která roli ochráni před jednotvárnosti a která s takovou opravdovostí

14 BIEDERMAN, Frhr. von. Die Quellen und Anlässe. Leipziger Zeitung: Wissenschaftliche Beilage der Leipziger Zeitung. Leipzig: Druck von B. G. Teubner, 1859, 38 (70, 71), s. 293-294.

15 WAGNER, Richard. Můj život. Praha: Národní divadlo v Praze, 2007, s. 162.

16 BATTA, András. OPERA. Composers. Works. Performers. England: Ullmann Publishing Gmbh, 2009 , s. 755.

17 GLASENAPP, Carl Friedrich. Das Leben Richard Wagners: Große Komponisten. Zweites Buch. Lochsberg: BiblioLife, 2009, s. 152. 
procházi napřič rejstřikem výrazů: neochvějná vážnost, přesvědčivá a důrazná výmluvnost, stejně jako mírné souzvuky citu." 18

Představení trvalo do půlnoci. S ohledem na abnormálně dlouhou délku opery Wagner druhého rána naléhavě spěchal do divadelní kanceláře, aby provedl škrty, kterými by rozsah opery zkrátil na únosný pro jeden divadelní večer. „Nevěřim“", jak sám vyprávěl, „že intendantura jinak můj kus ještě někdy bude dávat." Když poté Wagner ve dvě hodiny odpoledne znovu přišel, aby se přesvědčil, zda byly škrty dle jeho pokynů provedeny, nebot mínil, že dříve se nemůže žádnému ze zpěváků či hudebníků podívat do očí, dostalo se mu odpovědi: „Pane Wagnere, to bychom neměli škrtat, a to taky ne!“ a na jeho udivené „Proč?“ zaznělo: „Pan Tichatscheck je proti; řekl, že to nemáme škrtat!" Wagner se zasmál a mínil: „Stal se snad Tichatscheck jedním z mých nepřátel?"“19

Tichatscheck ovšem nebyl jediný, kdo se odmítavě stavěl vůči provedení skladatelových výňatků. Ostatní zpěváci sice jednomyslně prohlásili, že je to dílo nesmírně namáhavé, ale rovněž si nechtěli nechat cokoliv odstranit. Wagner v pozdějším dopise svým pařížským přátelům vyprávěl, že když Tichatschecka „ve vší skromnosti“ upozornil na to, že z jeho vysoce namáhavého partu mělo být něco vyjmuto, pěvec pokaždé jen odvětil: „Ne, nebot' je to přiliš nádherné! Nenechám si cokoli vyškrtnout, protože je to př́liš nádherné!" Přitom se oči nadšeného umělce zalily slzami. ${ }^{20}$ Tuto epizodu, poukazující na vášnivý Tichatscheckův vztah k Rienzimu, Wagner sám o třicet let později vyprávěl v Drážd’anech během jedné z oslav uspořádaných na jeho počest. Banketu byl účasten i Tichatscheck. Wagner si nakonec pomohl tím, že operu, kterou nechtěl škrty mrzačit, nechal provádět ve dvou dílech dva po sobě navazující večery (první a druhé dějství, a poslední tři dějství dohromady), díky čemuž se dostalo jak zpěvákům, tak i publiku podstatné úlevy.

Že byl skladatel vděčen Tichatscheckovi za přívětivé přijetí Rienziho nejen u publika, ale především u pěvců a orchestru, lze vyčíst z pozdějšího pařížského dopisu z roku 1860, kde Wagner psal o drážd’anském příteli při vzpomínce na významný večer. „Č́m dál nadšenějši zájem našeho Tichatschecka pro jeho úkol, pro celé dilo, se brzy, což se v našich dobách takřka nedá zažit, přenesl na ostatni povolané ke spolupráci, a drážd’anské publikum - skrze div nejuřelejšího zaujetí všech umělců štastně připravených na dílo někoho zcela neznámého - mne za té bouřlivé noci prvniho provedeni mého Rienziho vyneslo mezi jim osvojené milácky. " Wagnerovo uspokojení je také znát z další „Zprávy mým prátelưm“. „Veliký zájem zpěváků o mého Rienziho, obzvláště nanejuýš př́větivého, neobyčejně nadšeného a nesmírně nadaného zpěváka hlavni role, je mi nadobyčej př́jemný a povznášejici. Ona ryzi smyslná bouřlivost Rienziho zjeveni pưsobila tam, obzvláště v Drážd’anech, jmenovitě skrze kouzlo prostředků a prírozenosti hlavního zpěváka, na publikum omamně."22

18 Tamtéž.

19 RYCHNOVSKY, Ernst. Josef Alois Tichatschek. Gesellschaft zur Förderung Deutscher Wissenschaft, Kunst und Literatur in Böhmen. Deutsche Arbeit: Monatschrift für das geistige Leben der Deutschen in Böhmen. Prag: Karl Bellmann, 1906-07, 6, s. 819.

20 Tamtéž.

21 LANGER, Eduard. Deutsche Volkskunde aus dem östlichen Böhmen. Braunau i B.: Selbstverlag, 1908, (VIII.), s. 16 .

22 Tamtéž. 
První spolupráce Tichaschecka s Wagnerem se stala uměleckým zážitkem i pro jiné osobnosti, které dobře znaly poměry drážd’anského divadla. Sbormistr Heine o pěvci řekl: „I přes jeho Raoula, Adolara a všechny ostatní zárivié role jsem se u něj nikdy nenadál takového nadšení. Bylo a lze ho nazvat vpravdě inspirujicím.“ Dále také pronesl: „Tichatscheck je svoji roli nadšen už proto, že v ni měl hodně nových kostýmů a že si jím mohu být v každém př́padě naprosto jist."23 V̌̌eobecné nadšení dospělo svého vrcholu, když Tichatscheck coby první Rienzi, neustále zapálený pro národní svobodu, ve scéně z Fóra mocně rozechvělým hlasem zpíval: „Nicht Rom allein sei frei, ganz Italien sei frei!“ 24

Slova tehdy získala jeho důrazným a deklamačním přednesem na hlubším významu, který byl zjevný tisícům přítomných diváků, nadšených pro sjednocení Německa. ${ }^{25}$ Také závěrečná modlitba „Allmächtger Vater“ („Všemohoucí Otče“) byla vyvrcholením celé opery a u publika je stejně přijímána i dnes, byt se provádí především koncertně. Úspěšné uvedení Rienziho vyneslo Richardu Wagnerovi jmenování dvorním kapelníkem drážd’anského divadla. Jak píše v prvním vydání lipský týdeník Musikalisches Wochenblatt, nemalý podíl na tomto úspěchu měl Tichatscheck, jehož „výkon v titulni roli, vycházejicí z tvořivého ponořeni se do postavy, navic provedené s velkolepou bohatostí prostředkư, které má pěvec $k$ dispozici, měl účin věru strhujicí. ${ }^{26}$

Pochvalně se o Tichatscheckově Rienzim mimo Wagnera vyjadřovali Hector Berlioz i Franz Liszt. V roce 1843 navštívil Berlioz představení Rienziho a o Tichatscheckově pěveckém projevu se poté vyjadřoval v korespondenci. „Tichatscheck je tenor s čistým a pronikavým hlasem, který s narůstajici dramatičnosti projevu nabirá na síle a živelnosti. Jeho styl zpěvu je jednoduchý, avšak vkusný. " 27 Na tento popud napsal Berlioz ve svém díle Grande messe des morts (nebo též Requiem) v části Sanctus tenorové sólo přímo pro Tichatschecka. Z korespondence se lze dále dočíst, jaké dispozice Berlioz v Tichatscheckovi viděl směrem k jeho interpretačnímu umu a proč byl pěvec předobrazem umělce další významné skladatelské osobnosti. „Je dokonalý listař a hudebnik. Na prvni pohled a bez výhrad, bez přetvářky a jakéhokoliv predstíráni. "28 Pěvec neušel ani pozornosti věhlasného Franze Liszta, v jehož korespondenci Richardu Wagnerovi stojí zmínka: „Tichatscheck je jako umělec bezesporu hodný obdivu. "29 Franz Liszt ostatně s Tichatscheckem ještě později spolupracoval, a to v roli dirigenta, o čemž se zmiňujeme v souvislosti s Lohengrinem.

23 WAGNER, Richard. Mi̊j život. Praha: Národní divadlo v Praze, 2007, s. 189.

24 STEMMLE, Rolf. Feen. Liebesverbot. Rienzi. Richard Wagners vielschichtige Opern eingängig erzhält. Würzburg: Verlag Königshausen \& Neumann, 2009, s. 109.

25 Dopad opery Rienzi na Wagnera se později projevil i při jeho revolučních myšlenkách a aktivitách.

26 SCHULZE, Carl. III. Biographien: Joseph Tichatschek. Musikalisches Wochenblatt: Organ für Tonkünstler und Musikfreunde. Leipzig: Verlag von E. W. Fritzsch, 1870, 1 (43), s. 680.

27 NEWMAN, Ernest. Memoirs of Hector Berlioz from 1803 to 1865: comprising his travels in Germany, Italy, Russia, and England. New York, 1932, s. 289-290.

28 Tamtéž.

29 GLASENAPP, Carl Friedrich. Das Leben Richard Wagners: Große Komponisten. Loschberg, 2009 , s. 43. 


\section{Bludný Holand'an a "světová premiéra" (1843)}

Dne 2. ledna roku 1843 měla v Drážd’anech světovou premiéru Wagnerův Bludný Holand’an. Wagner původně drama odeslal do Mnichova a Lipska, nicméně se mu z obou míst dostalo zamítavých odpovědí. V Berlíně zprostředkoval později přijetí tohoto díla Meyerbeer, což ale, jak se Wagner vyjádřil, „,nebylo nic víc než uměle zařízený, zbytečný a veskrze bezvýsledný důkaz ochoty pomoci“. Lze přičíst úspěchu Rienziho, že se po několika měsících podařilo provedení Holand’ana v Drážd’anech uskutečnit. Valný úspěch, jako v předešlém př́ípadě, ovšem neslavil. Možná i z důvodů, které míní Prölß: „nebot se uvnitř ukazuje osobitost umělcova mnohem samostatněji, svobodněji a žretelněji “. ${ }^{30}$

Při studiu materiálů o pěvci Tichatscheckovi jsme narazili na zajímavou informaci ve věci jeho účinkování ve světové premiéře opery Bludný Holand’an. Materiál s výčtem Tichatscheckových rolí v Královském divadle v Drážd’anech, ${ }^{31}$ který nám poskytl institut Sächsische Staatstheater, resp. oddělení Historisches Archiv (Historický archiv Saského státní ho divadla), uvádí, že světovou premiéru dne 2. ledna 1843 skutečně zpíval Tichatscheck, byt v tomto dramatu není hlavní role pro tenorový part, nýbrž pro hlasy hluboké. V Holand’anovi dokonce nevystoupil ani ve větší roli Erika - tu ztvárnil Friedrich Traugott Reinhold ${ }^{32}$ - ale údajně v roli Steuermanna (kormidelníka). I přes důkladné bádání bylo obtížné dohledat bližší informace v souvislosti s Tichatscheckovým účinkováním, nebot nejde o Wagnerovo stěžejní dílo, a většina zpráv z divadelních programů obsahuje strohou poznámku k prvnímu premiérovému provedení. Zde uvádí u role kormidelníka pražského rodáka a tenoristu Wenzela Bieleczizkého. ${ }^{33}$

30 PRÖLß, Robert. Geschichte des Hoftheaters zu Dresden: Von seinen Anfängen bis zum Jahre 1862. Dresden: Wilhelm Baensch Verlagshandlung, 1878, s. 536.

31 Sächsische Staatstheater Staatsoper. Dresden und Staatsschauspiel Dresden. Handschriftliches Rollenverzeichnis. [Nesignováno].

32 Friedrich Traugott Reinhold (1817-1843) byl synem obuvníka. Ve třinácti letech přišel do Thomasschule v Lipsku, kde byl přijat do slavného Thomanerchor. Od roku 1838 byl chorálovým prefektorem, ale v témže roce začal studovat právo na univerzitě v Lipsku. Ředitel lipského divadla Ringelhardt ho nechal zpívat ve sboru a dal mu první menší role. Během této doby byl Reinhold dále vzděláván lipským pedagogem Schmidtem. Režisér Fischer z drážd’anského Královského divadla ho přiměl, aby přesídlil do saského hlavního města a stal se členem operního sboru. V Drážd’anech účinkoval ve dvou premiérách představení Richarda Wagnera (v Rienzim jako Baroncelli a v Bludném Holand’anovi jako Erik). Zdroj: KUTSCH, K. J. a Leo RIEMENS. Großes Sängerlexikon: Vierte, erweiterte und aktualisierte Auflage. 4. München: K. G. Saur Verlag, 2003, s. 3881.

WAGNER, Richard. Můj život. Praha: Národní divadlo v Praze, 2007, s. 198.

33 Wenzel Bieleczizky (1818-1865), též Bielezizky. Tenorista, který začal svoji kariéru v operních divadlech Rakousko-Uherska a postupně zpíval v operních domech v Zagrebu (Záhřeb) a Lubljani (Lublani). Dočasně působil též ve Vídni. Jako host se představil v Královském divadle v Drážd’anech v roce 1841 (Arturo v Puritánech a Pollioni v Belliniho Normě). Dále zde působil jako lyrický tenor až do roku 1847. Dle mnoha zdrojů údajně zpíval dne 2. ledna 1843 v prvním provedení Bludného Holand’ana jako Steuermann po boku Schröder-Devrientové a dalších. Po odchodu z Drážd’an v letech 1847-1848 vystupoval v Salcburku a živil se jako učitel hudby. Zdroj: KUTSCH, K. J. a Leo RIEMENS. Großes Sängerlexikon: Vierte, erweiterte und aktualisierte Auflage. 4. München: K. G. Saur Verlag, 2003, s. 411. 
Dokonce i Wagner se o obsazení Tichatschecka zmiňuje velmi neurčitě, že tam pro něj [Tichatschecka] nebyla velká pěvecká role, a tuto domněnku tedy nepotvrzuje ani nevyvrací. ${ }^{34}$

Při studiu ročenek z let 1838-1848 v Drážd’anské státni knihovně jsme byli svědkem šestadvaceti případů, kdy divadlo na plakátu ohlásilo představení, které bylo záhy zrušeno, změněno nebo se jednoduše proměnila sestava vystupujících. V takové situaci byl vždy plakát pouze v den představení ručně přeškrtnut a informace v něm upraveny. Je tedy skutečně možné, že k takové úpravě došlo i zde; obzvláště když informaci o premiéře pěvce Tichatschecka poskytl institut přímo spadající pod organizaci divadla a spojený s pěvcovým nejdelším životním angažmá. Navíc v poznámce u Tichatscheckovy premiéry Holand’ana se dále uvádí, že je většinou u role psán právě Bieleczizky. To by znamenalo, že s touto skutečností byl obeznámen i autor zmiňovaného výčtu rolí.

V lipském Stadtgeschichtliches Museum Leipzig byl k dispozici dokument, resp. notový zápis ${ }^{35}$ který je Tichatscheckovým autografem a je přepisem úvodní Písně námořníků „Mitt Gewitter und Sturm aus fernem Meer" z Bludného Holand'ana. Tento autograf může rovněž představovat Tichatscheckovu participaci na představení.

Další nalezený materiál, který by potvrzoval, že Tichatscheck ve světové premiéře vystoupil, je kniha Vademecum für Wagnerfreunde, která k představení uvádí: „Po krátkém pobytu v Lipsku (listopad 1842) se Wagner seznámil a začal komunikovat s Mendelssohnem, Schumannem a Heinrichem Laubem. Vrátil se do Drážd'an a začal zkoušet Bludného Holand'ana, podporován Fischerem, Tichatscheckem a tehdy se vracejici Schröder-Devrientovou. Dokonce se pred proním představením jeho druhé opery uskutečnilo před přeplněným domem jmenováni Wagnera dirigentem dráždianského Dvorního divadla (2. ledna 1843).

$\begin{array}{ll}\text { Obsazení jednotlivých rolí bylo následující: } \\ \text { Daland, norský námořník } & \text { pan Dettmer } \\ \text { Senta, jeho dcera } & \text { pani Schröder-Devrientová } \\ \text { Erik, rybář } & \text { pan Reinhold } \\ \text { Mary, sestra Senty } & \text { pani Wächterová } \\ \text { Dalandĩv kormidelník } & \text { pan Tichatscheck } \\ \text { Holand’an } & \text { pan Wächter. “36 }\end{array}$

Dále se pak v textu uvádí, kterak byl Bludný Holand’an v porovnání s předešlým Rienzim publikem odmítnut, přičemž premiérové představení nezachránila ani Schröder-Devrientová, což dojem z Wagnerova jmenování do funkce dirigenta zajisté poněkud pokazilo. Nakolik za to již mohlo nevhodné obsazení Dettmera do role Holand’ana, či fakt, že Holand’an postrádá v ústředních rolích tenorový hlas, zůstává nezodpovězeno.

34 WAGNER, Richard. Mi̊j život. Praha: Národní divadlo v Praze, 2007, s. 198.

35 Stadtgeschichtliches Museum Leipzig. Korrespondenzen. Stammbuchblatt, 1. Bl. Sig. A/2014/478.

36 CHARLES CHOP, Max. Vademecum für Wagnerfreunde Führer durch Richard Wagner's Tondramen (mit über 400 Notenbeispielen): Der fliegende Holländer. Die Vorgeschichte der Oper. Leipzig: Verlag der Serig'schen Buchhandlung, 2016, s. 9-10. 
Nicméně informace o Tichatscheckově účinkování ve světové premiéře Bludného Holand’ana může znamenat, že se v současné době ve většině světových programů uvádí v prvním provedení mylně jméno Bieleczizkého namísto Tichatschecka, a stejně tak by byla dosud Tichatscheckovi upírána světová premiéra dalšího Wagnerova představení, což se v našich očích nyní jeví jako velmi pravděpodobné.

\section{Bibliography}

BAITZEL, Edgar. Richard Wagner. Rienzi, der Letzte der Tribunen: Bayrische Staatsoper München. München: Herstellung und Druck J. Gotteswinter, 1983.

BATTA, András. OPERA. Composers. Works. Performers. England: Ullmann Publishing GmbH, 2009. BIEDERMAN, Frhr. von. Die Quellen und Anlässe. Leipziger Zeitung: Wissenschaftliche Beilage der Leipziger Zeitung. Leipzig: Druck von B. G. Teubner, 1859, 38 (70, 71).

BROCKHAUS, F. U. Rienzi, der Letzte der Tribunen: Große tragische Oper in fünf Acten von Richard Wagner. Illustrirte Zeitung: Leipzig, Berlin, Wien, Budapest, New York: Wöchentliche Nachrichten über alle Tagesgeschichte, öffentliches und gesellschaftliches Leben, Wissenschaft und Kunst, Musik, Theater und Moden. Leipzig: Verlag der Expedition der Illustrirten Zeitung J. J. Weber, 1843,1 (7).

DEMBSKI, Max. Feuilleton. Münchener allgemeine Zeitung. Dresden: Verlag der Expedition der Illustrirten zeitung J. J. Weber, 1907, 22 (316).

ESCHEBACH, Erika a Erik OMLOR. Richard Wagner in Dresden. Mythos und Geschichte. Dresden: Stadtmuseum Dresden, 2013.

FRIEDMANN, Ferdinand Maria. Tagschgeschichte: Aus Berlin. Journalistik das historische Lustspiel von Zahlhas Gastspiele. Neues Tagblatt für München und Bayern. München: Herausgegeben und verlegt von Ferd. Maria Friedmann und R. Lemburg, 1839, 90 (170).

FÜRSTENAU, Moritz. Eine biographische Skizze nach handschriftlichen und Gedruckten Quellen. Leipzig: Verlag von Gustav Heinze, 1868.

GIRSCHNER, C. F. J. III. Berichte: Wien. Berliner Musikalische Zeitung. Berlin: Verlegt und Gedruckt von L. W. Crause, 1833, (100).

GLASENAPP, Carl Friedrich. Das Leben Richard Wagners: Große Komponisten. Lochsberg: BiblioLife, 2009 .

GLASENAPP, Carl Friedrich. Das Leben Richard Wagners: Große Komponisten. Fünfter Band. Lochsberg: BiblioLife, 2009.

CHARLES CHOP, Max. Vademecum für Wagnerfreunde Führer durch Richard Wagner's Tondramen (mit über 400 Notenbeispielen): Der fliegende Holländer. Die Vorgeschichte der Oper. Leipzig: Verlag der Serig'schen Buchhandlung, 2016.

ISOLANI, Eugen. Der este Wagnersänger: zum hundertjährigen Geburstage Tichatscheks. Neuer Theater Almanach: der Deutschen Bühnengenosseschaft vom Jahre 1907. Berlin: Druck und komissions Verlag von F. U. Günther \& Sohn., 1907, 18.

J., O. Tenorista Ticháček: Jubileum 1863. Dalibor: Časopis pro hudbu, divadlo a uměni vi̊bec. Praha: Robert Veit, 1863, 5 (6).

KUČERA, Jan P. Drama zrozené hudbou. Litomyšl: Paseka, 1995.

KUTSCH, K. J. a Leo RIEMENS. Großes Sängerlexikon: Vierte, erweiterte und aktualisierte Auflage. 4. München: K. G. Saur Verlag, 2003. 
LANGER, Eduard. Deutsche Volkskunde aus dem östlichen Böhmen. Braunau i B.: SelbstVerlag, 1908, (VIII.).

MELIŠ, Emanuel. Slavný český wagnerovský pěvec. Dalibor: Hudebni časopis s měsični notovou př́lohou. Praha: Robert Veit, 1859, 2 (9).

NEWMAN, Ernest. Memoirs of Hector Berlioz from 1803 to 1865: comprising his travels in Germany, Italy, Russia, and England. New York: Tudor Publishing, 1932.

PRÖLß, Robert. Geschichte des Hoftheaters zu Dresden: Von seinen anfängen bis zum jahre 1862. Dresden: Wilhelm Baensch Verlagshandlung, 1878.

RYCHNOVSKY, Ernst. Josef Alois Tichatschek. Gesellschaft zur Förderung Deutscher Wissenschaft, Kunst und Literatur in Böhmen. Deutsche Arbeit: Monatschrift für das geistige Leben der Deutschen in Böhmen. Prag: Karl Bellmann, 1906-07, 6.

SCHULZE, Carl. III. Biographien: Joseph Tichatschek. Musikalisches Wochenblatt: Organ für Tonkünstler und Musikfreunde. Leipzig: Verlag von E. W. Fritzsch, 1870, 1 (43).

Stadtgeschichtliches Museum Leipzig. Korrespondenzen. Stammbuchblatt, 1. Bl. Sig. A/2014/478.

STEMMLE, Rolf. Feen. Liebesverbot. Rienzi. Richard Wagners vielschichtige Opern eingängig erzhält. Würzburg: Verlag Königshausen \& Neumann, 2009.

STERNFELD, Richard. Zu C. Fr. Glasenapps sechzigstem Geburstag: Leitartikel, Biographien etc. Musikalisches Wochenblatt: Organ für Musiker und Musikfreunde. Neue Zeitschrift für Musik. Berlin. Leipzig. Wien: Kommissions-Verlag von G. Kreysing, 1907, 38 (40).

WAGNER, Richard. Můj život. Praha: Národní divadlo v Praze, 2007. 